\title{
Oblique Aerial Photography of the Arctic Coast of Alaska, Nulavik to Demarcation Point, August 7-10, 2006
}

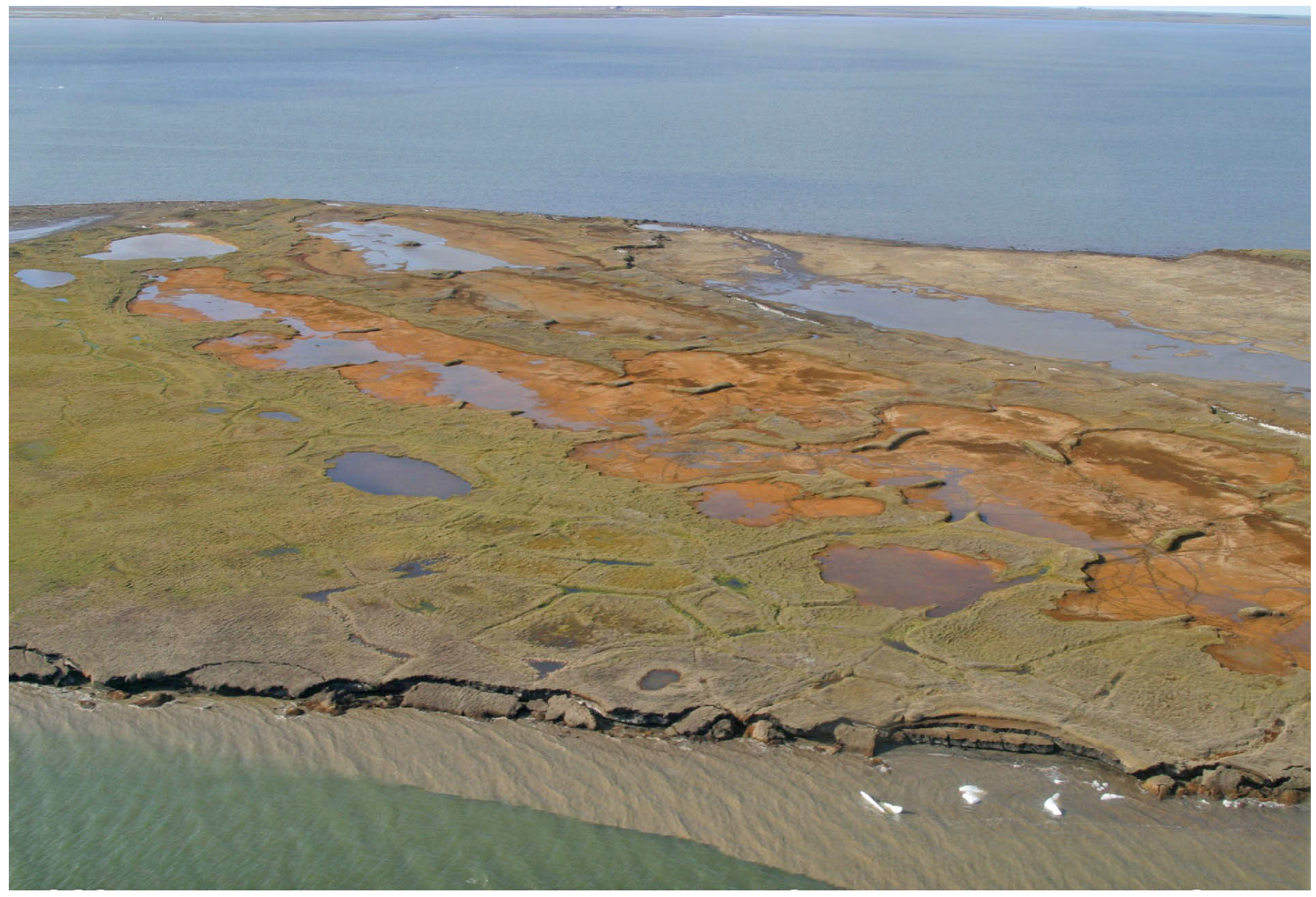

Data Series 436 
Typical photographic image from survey A-1-06-AK. 


\section{Oblique Aerial Photography of the Arctic Coast of Alaska, Nulavik to Demarcation Point, August 7-10, 2006}

By Ann E. Gibbs and Bruce M. Richmond

Data Series 436 


\title{
U.S. Department of the Interior \\ KEN SALAZAR, Secretary
}

\author{
U.S. Geological Survey \\ Suzette M. Kimball, Acting Director
}

U.S. Geological Survey, Reston, Virginia: 2009

For more information on the USGS - the Federal source for science about the Earth, its natural and living resources, natural hazards, and the environment:

World Wide Web: http://www.usgs.gov/pubprod

Telephone: 1-888-ASK-USGS (1-888-275-8747)

This report and any updates to it are available online

at: http://pubs.usgs.gov/ds/436/

Suggested citation:

Gibbs, A.E. ,and Richmond, B.M., 2009. Oblique aerial photography of the Arctic coast of Alaska, Nulavik to Demarcation Point, August 7-10, 2006: U.S. Geological Survey Data Series 436, 6 p.

Any use of trade, product, or firm names is for descriptive purposes only and does not imply endorsement by the U.S. Government.

Although this report is in the public domain, permission must be secured from the individual copyright owners to reproduce any copyrighted material contained within this report.

Cataloging-in-publication data are on file with the Library of Congress (http://www.loc.gov/) 


\section{Contents}

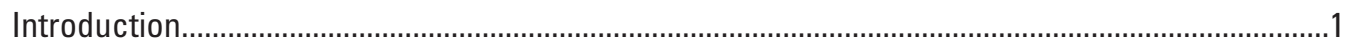

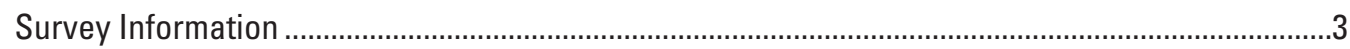

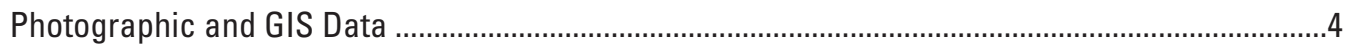

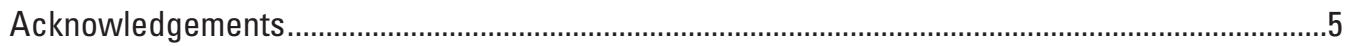

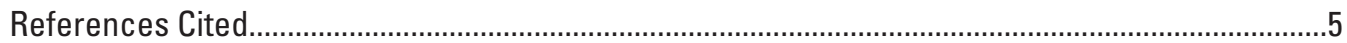

\section{Figures}

1. North Slope of Alaska from the United States-Canadian border on the east to the Barrow Peninsula on the west showing flightlines of survey A-1-06-AK for individual days...................2

2. North Slope of Alaska, from the United States-Canadian border on the east to the Barrow Peninsula on the west showing the extent of coastal photographic coverage ..........................

3. Survey platform, Cessna 185 Skywagon II floatplane, piloted by Jim Webster of Fairbanks.......... 4

4. Typical photographic image from survey A-1-06-AK, annotated with location, collection time,

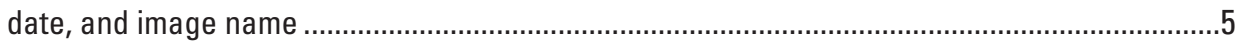

\section{Tables}

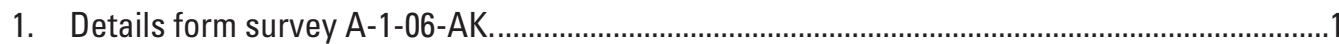


This page intentionally left blank 


\title{
Oblique Aerial Photography of the Arctic Coast of Alaska, Nulavik to Demarcation Point, August 7-10, 2006
}

\author{
By Ann E. Gibbs and Bruce M. Richmond
}

\section{Introduction}

The Arctic Coastal Plain of northern Alaska, an area of strategic economic importance to the United States, is home to remote Native American communities and encompasses unique habitats of global significance. Coastal erosion along the Arctic coast is chronic and widespread; recent evidence suggests that erosion rates are among the highest in the world (up to $\sim 16 \mathrm{~m} / \mathrm{yr}$ ) and may be accelerating (Mars and Houseknecht, 2007; Jones and others, 2008). Coastal erosion adversely impacts energy-related infrastructure, natural shoreline habitats, and Native American communities. Climate change is thought to be a key component of recent environmental changes in the Arctic (Hinzman and others, 2005). Reduced sea-ice cover in the Arctic Ocean is one of the probable mechanisms responsible for increasing coastal exposure to wave attack and the resulting increase in erosion (Reimnitz and Maurer, 1979; Jorgenson and Brown, 2005). Extended periods of permafrost melting and associated decrease in bluff cohesion and stability are another possible source of the increase in erosion.

Several studies of selected areas on the Alaska coast document past shoreline positions and coastal change, but none have examined the entire North coast systematically (Harper, 1978; Reimnitz and others, 1985, 1988; Barnes and others, 1992; Mars and Houseknecht, 2007; Jones and others, 2008). Results from these studies indicate high rates of coastal retreat that vary spatially along the coast. To address the need for a comprehensive and regionally consistent evaluation of shoreline change along the North coast of Alaska, the U.S. Geological Survey (USGS), as part of their Coastal and Marine Geology Program's (CMGP) National Assessment of Shoreline Change Study, is evaluating shoreline change from Peard Bay to the United States/Canadian border, using historical maps and photography and a standardized methodology that is consistent with other shoreline-change studies along the Nation's coastlines (for example, URL http:// coastal.er.usgs.gov/shoreline-change/ (last accessed March 2, 2009); Hapke and others, 2006).
This report contains photographs collected during an aerial-reconnaissance survey conducted in support of this study. An accompanying ESRI ArcGIS shape file (and plaintext copy) indicates the position of the aircraft and time when each photograph was taken. The USGS-CMGP Field Activity ID for the survey is A-1-06-AK, and more information on the survey and how to view the photographs using Google Earth software is available online at: URL http://walrus.wr.usgs. gov/infobank/a/a106ak/html/a-1-06-ak.meta.html (last accessed March 2, 2009).

\section{Survey Information}

More than 3,000 digital still photographs were taken over three survey days (Aug 7-10, 2006) between Nulavik, Alaska ( $\sim 60 \mathrm{~km}$ southwest of Barrow), and the United States/ Canadian border (fig. 1; table 1). Although some gaps exist around river deltas and elsewhere due to the presence of fog banks or rain, total coverage is estimated at more than 80

Table 1. Details from survey A-1-06-AK.

\begin{tabular}{|c|c|c|l|l|}
\hline $\begin{array}{c}\text { Date } \\
\text { 2006. }\end{array}$ & $\begin{array}{c}\text { No. of } \\
\text { photo- } \\
\text { graphs }\end{array}$ & $\begin{array}{c}\text { GPS rate } \\
\text { (Sec- } \\
\text { onds) }\end{array}$ & Area covered & Image filenames \\
\hline 7 & 482 & 5 & $\begin{array}{l}\text { Deadhorse- } \\
\text { Cross Island- } \\
\text { Leavitt Island- } \\
\text { Deadhorse }\end{array}$ & $\begin{array}{l}\text { IMG_7524.jpg } \\
\text { IMG_8012.jpg }\end{array}$ \\
\hline 8 & 976 & 10 & $\begin{array}{l}\text { Deadhorse- } \\
\text { Canadian } \\
\text { Border- } \\
\text { Deadhorse }\end{array}$ & $\begin{array}{l}\text { IMG_8017.jpg } \\
\text { IMG_9054.jpg }\end{array}$ \\
\hline 9 & 1609 & 6 & $\begin{array}{l}\text { Dulavik- } \\
\text { Deadhorse }\end{array}$ & $\begin{array}{l}\text { DCS05263.jpg } \\
\text { IMG_0790.jpg } \\
\text { IMG_9058.jpg } \\
\text { IMG_0015.jpg } \\
\text { IMG_9869.jpg }\end{array}$ \\
\hline
\end{tabular}




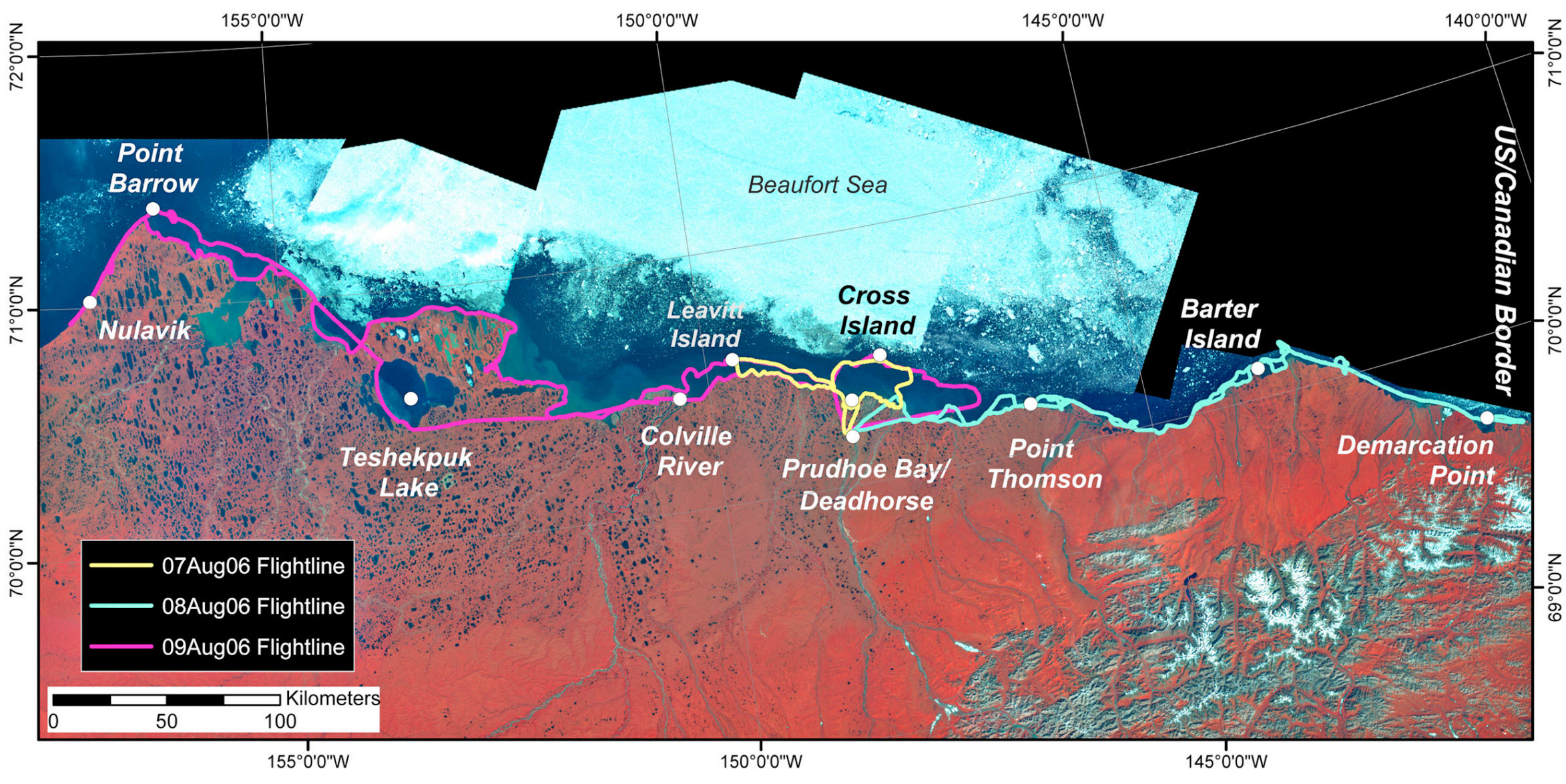

Figure 1. North Slope of Alaska from the United States-Canadian border on the east to the Barrow Peninsula on the west showing flightlines of survey A-1-06-AK for individual days. Base is a spectrally enhanced Landsat-MSS mosaic (1977-86 composite), available for download at http://agdc.usgs.gov/data/projects/anwr/datahtml/ ns124_mss.html (last accessed March 2, 2009). 


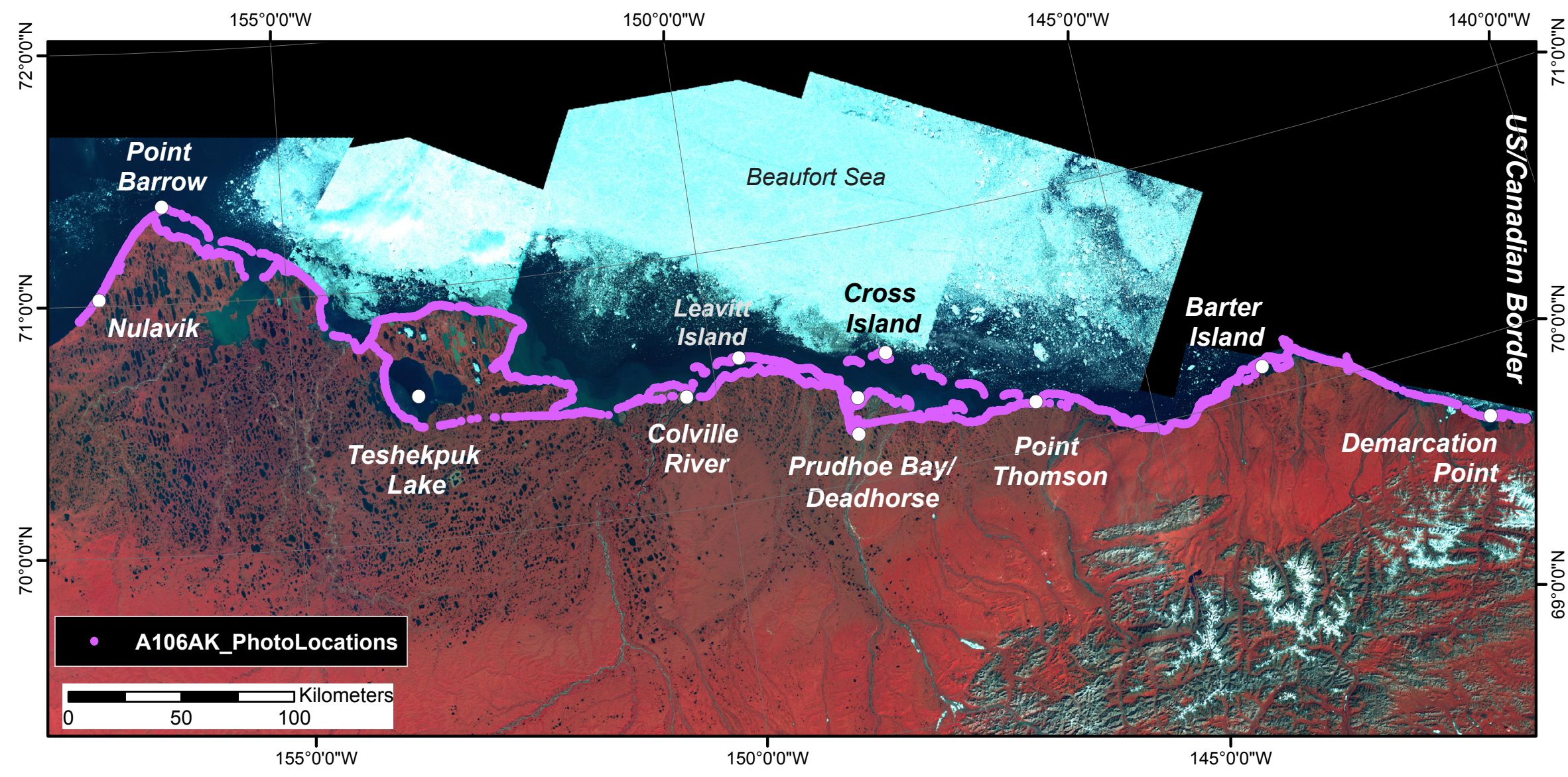

Figure 2. North Slope of Alaska, from the United States-Canadian border on the east to the Barrow Peninsula on the west showing the extent of coastal photographic coverage (magenta dots). 
percent (fig. 2). High-definition video imagery was collected concurrently but is not included in this data release.

Field operations were based out of Deadhorse, Alaska, a small town located at the end of the Dalton Highway near Prudhoe Bay and the start of the Trans-Alaska Pipeline. Photographs were collected from a Cessna 185 Skywagon II floatplane (fig. 3), typically at an altitude of about $500 \mathrm{ft}$ (152 $\mathrm{m}$ ) and approximately 1,000 ft (305 m) offshore. The primary camera was a 6.3-megapixel Canon EOS D60, with a 24 to 85 mm zoom lens (IMG_iiii.jpg filename format, where "iiii" is an image counter). A 5-megapixel Sony DSC-T1, "point and shoot" camera was also used on August 10 (DSCiiii.jpg filename format, where "iiii" is an image counter). In general, photographs were taken with the largest field of view; however, the photographer could also zoom in to collect more detailed photographs of features of interest. Because of variable aircraft altitude and distance from the shoreline, as well as variable shooting parameters, the photographs do not show a consistent image width.

A Garmin GPSmap 76CS (WAAS enabled) handheld global-positioning-system (GPS) unit recorded the position of the aircraft every 5-10 s (table 1). All the imagery was georeferenced to the aircraft position at the time when each photograph was taken, annotated with position and time information, resampled (to 2,000 by 1,333 pixels), and compressed (to 90 percent original .jpg quality) using software and hardware developed by Red Hen Systems (URL http:// redhensystems.com (last accessed March 2, 2009); fig. 4).

\section{Photographic and GIS Data}

This report includes survey photographs, separated into folders by survey day; an ArcGIS shapefile and comma-separated plaintext file "A106AK_PhotoLocations"; and metadata files. Attributes include the location of the aircraft (longitude, latitude, altitude) and UTC when each photograph was taken, the image "NAME", and the field "IMAGE" that denotes the location of the image file.

The imagery included in this report is viewable in multiple ways. Photographs can be opened directly by using any .jpg-compatible image viewer (for example, Windows Picture and Fax Viewer, Quicktime Picture Viewer, Adobe Photoshop, or any Web browser), and thumbnails of images can be viewed directly within Windows Explorer by selecting the "View-Thumbnails" option.

The shapefile "A106AK_PhotoLocations" included in this report facilitates viewing within an ArcMap GIS project. Once the shapefile is added to the project, hyperlinks can be enabled and photographs viewed by using the default .jpg-file image viewer. Images are best viewed in Windows Picture and Fax Viewer or another viewer that provides the ability to scroll backward and forward along the flightline. To maintain the integrity of hyperlinks if copied to another location, photograph folders should be stored in the same-level folder as the shapefile "A106AK_PhotoLocations".

To enable hyperlinks, select "IMAGE" as the supported "Hyperlinks" field on the "Display" tab within the "Layer

Figure 3. Survey platform, Cessna 185 Skywagon II floatplane, piloted by Jim Webster of Fairbanks.

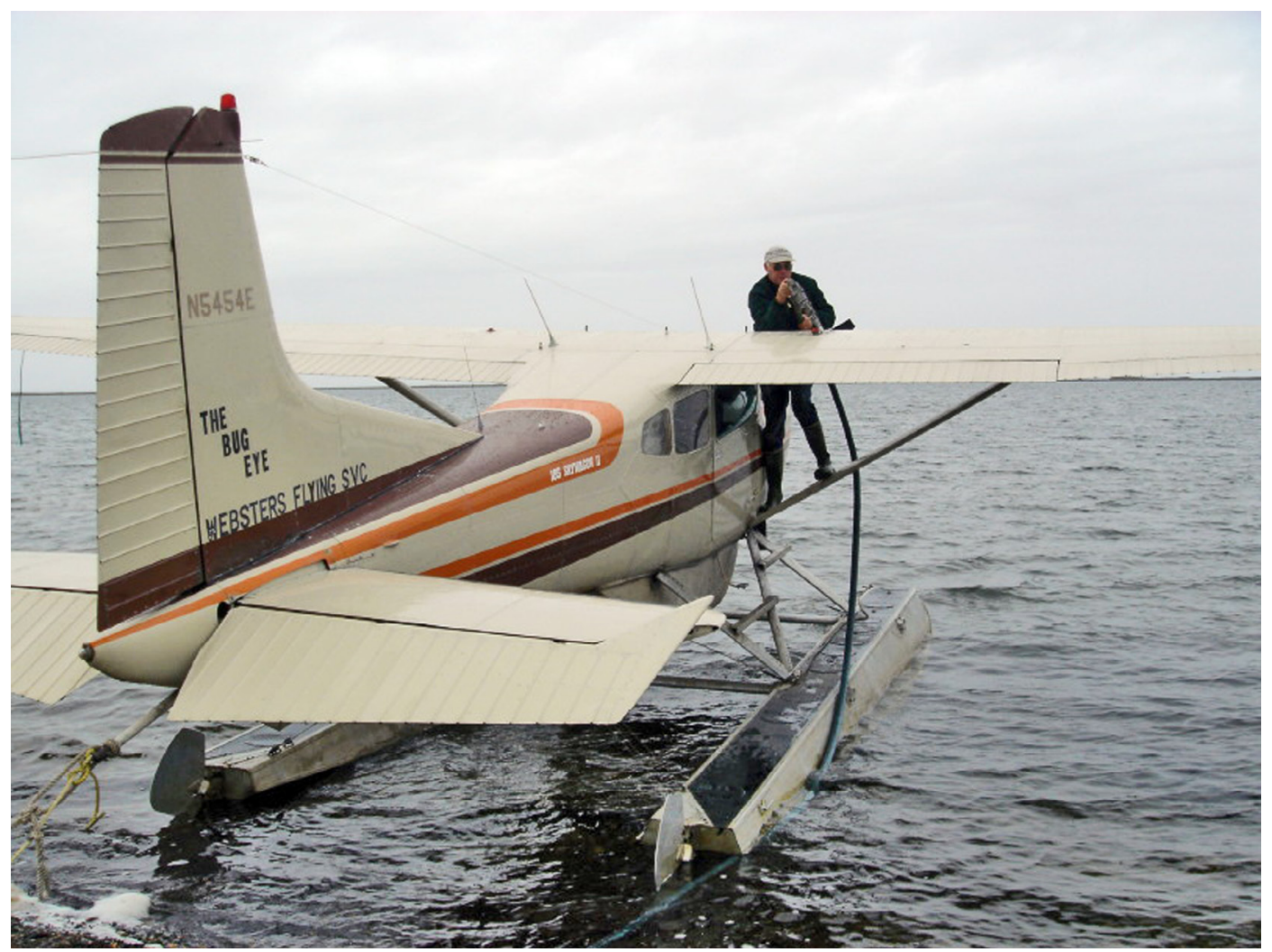




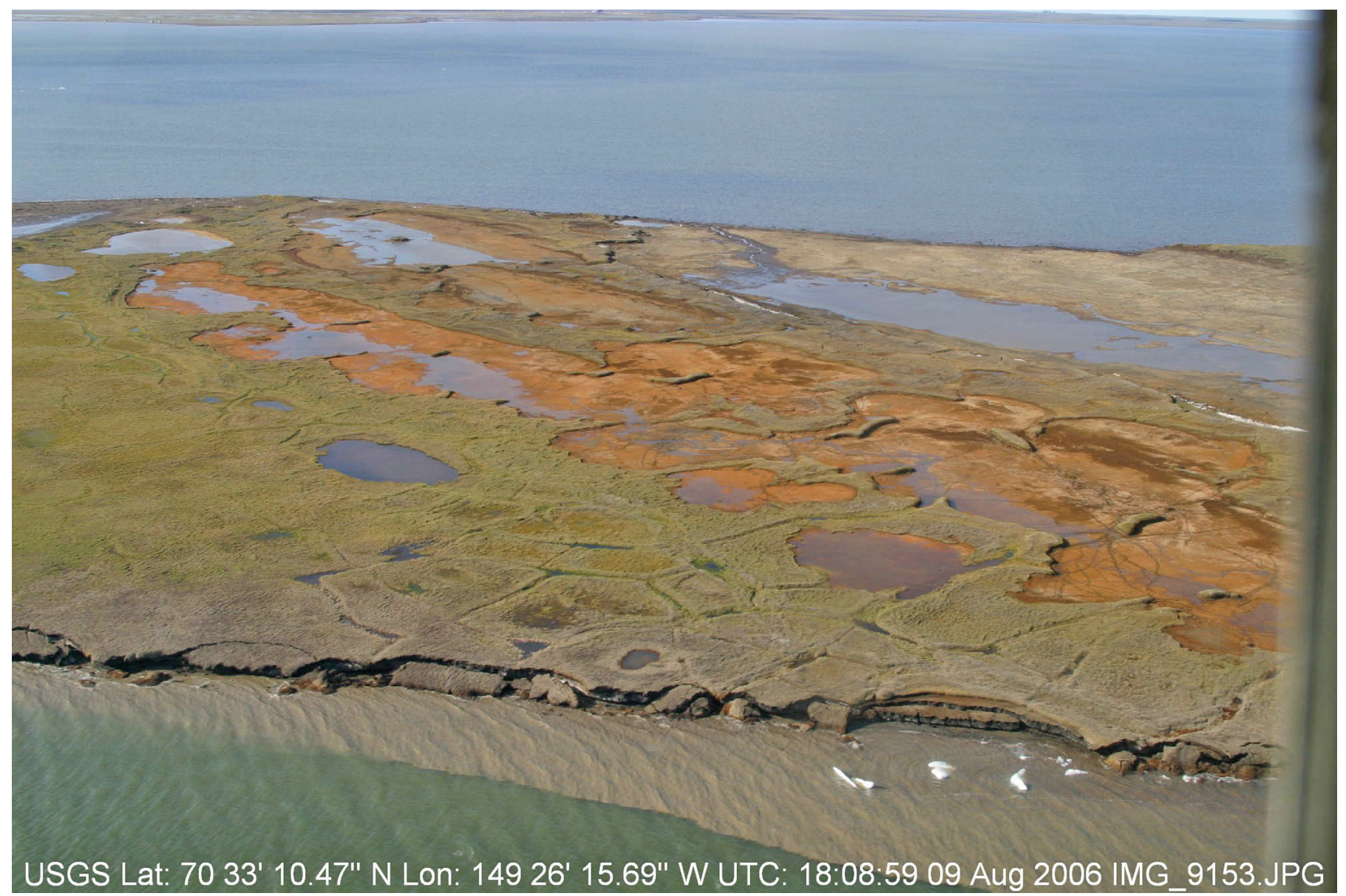

Figure 4. Typical photographic image from survey A-1-06-AK, annotated with location, collection time, date, and image name.

Properties" dialog box for "A106AK_Photolocations". The "Hyperlink base" field in the "Document Properties" dialog box under the "File" menu must also indicate the full path to the files. (For example, if your download drive is labeled " $\mathrm{H}$ ", the "Hyperlink base" field should be modified to "H:".) Once hyperlinks are established, photographs can be viewed by selecting a point with the "Hyperlink" button on the toolbar. Hyperlinked photos can also be accessed by using the "Identify" tool if the "IMAGE" attribute is modified to reflect the full, versus relative, pathname.

Information included in this report is considered public domain and may be freely copied and distributed. Use of appropriate byline/photograph/image credit is requested; suggested credit: photograph by Bruce Richmond/Ann Gibbs, USGS (or U.S. Geological Survey, depending on audience).

\section{Acknowledgments}

Funding for this project was provided by the USGS Coastal and Marine Geology Program and the USGS Alaska Science Center. Jim Webster of Fairbanks capably and safely piloted us in "The Bug Eye" (fig. 3) and protected us from polar bears. Joel Schmutz of USGS provided much-appreciated logistical support.

\section{References Cited}

Barnes, P.W., Reimnitz, E., and Rollyson, B.P., 1992, Map showing Beaufort Sea coastal erosion and accretion between Flaxman Island, northeastern Alaska, and the Canadian border: U.S. Geological Survey Miscellaneous Investigations Series Map I-1182-H, 22 p., scale $1: 82,000$.

Hapke, C.J., Reid, D., Richmond, B.M., Ruggiero, P., and List, J., 2006, National Assessment of Shoreline Change; Part 3, Historical shoreline change and associated coastal land loss along sandy shorelines of the California coast: U.S. Geological Survey Open-File Report 20061219 [http://pubs.usgs.gov/of/2006/1219 last accessed March 2, 2009]. 
Harper, J.R., 1978, Coastal erosion rates along the Chukchi Sea coast near Barrow, Alaska. Arctic, v. 31, no. 4, p. 428-433.

Hinzman, L.D. and 34 others, 2005, Evidence and implications of recent climate change in northern Alaska and other Arctic regions: Climatic Change, v. 72, p. 241-298.

Jones, B.M., Hinkel, K.M., Arp, C.D., and Eisner, W.R., 2008, Modern erosion rates and loss of coastal features and sites, Beaufort Sea coastline, Alaska: Arctic, v. 61 no. 4, p. 361-372.

Jorgenson, M.T., and Brown, J., 2005, Classification of the Alaskan Beaufort Sea coast and estimation of carbon and sediment inputs from coastal erosion: Geo-Marine Letters, v. 25 , p. 69-80.
Mars, J.C., and Houseknecht, D.W., 2007, Quantitative remote sensing study indicates doubling of coastal erosion rate in the past $50 \mathrm{yr}$ along a segment of the Arctic coast of Alaska: Geology, v. 35, no. 7, p. 583-586.

Reimnitz, E., Graves, S.M., and Barnes, P.W., 1985, Beaufort Sea coastal erosion, shoreline evolution, and sediment flux: U.S. Geological Survey Open-File Report 85-380, 67 p.

Reimnitz, E., Graves, S.M., and Barnes, P.W., 1988, Beaufort Sea coastal erosion, sediment flux, shoreline evolution, and the erosional shelf profile: U.S. Geological Survey Miscellaneous Investigations Series Map I-1182-G, 22 p., scale 1:82,000.

Reimnitz, E., and Maurer, D.K., 1979, Effects of storm surges on the Beaufort Sea coast, northern Alaska: Arctic, v. 32, no. 4 , p. 329-344. 
inside back cover 
蛋

믐

을

ำ

큼

c

들

ำ

국

훙

흠

0

के

곡.

๑ั.

음

궁

츨

를

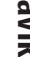

a

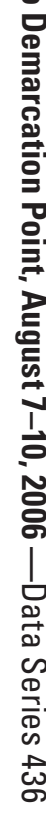

